\title{
Intensification of Land and Building Tax Collection in The Barru Regency Revenue Service
}

\author{
Muh. Nasrullah* \\ Department Office Administration \\ Education \\ Universitas Negeri Makassar \\ Makassar, Indonesia \\ nasrullah.mujetaba@unm.ac.id
}

\author{
Muhammad Luthfi Siraj \\ Department Bussines Administration \\ Universitas Negeri Makassar \\ Makassar, Indonesia \\ lutfi@gmail.com
}

\author{
Sitti Hardiayanti Aras \\ Department Office Administration \\ Education \\ Universitas Negeri Makassar \\ Makassar, Indonesia \\ hardiayantiarhas@unm.ac.id
}

\begin{abstract}
This research was conducted to determine the intensification of Land and Building Tax (PBB) collection at District Revenue Office (DISPENDA) of Barru in terms of the aspects of counseling, services, and audits, and to determine efforts to improve the quality of tax collector employees at District Revenue Office (DISPENDA) of Barru. This study used a descriptive type with a qualitative approach to make direct observations of the object under study by analyzing the data obtained through an interactive model. The results show that the intensification of Land and Building Tax (PBB) collection at District revenue office (DISPENDA) of Barru seen from the aspect of counseling, it has been carried out quite well and the service aspect whose implementation is still not good, while the inspection aspect and its implementation are not going well. Overall, the intensification of Land and Building Tax (PBB) collection at District Revenue Office (DISPENDA) of Barru has not carried out properly. The increasing of quality of tax collector employees at District Revenue Office (DISPENDA) of Barru have gone well. This is because the leader has tried to always improve the quality of his employees by providing training and education that aimed at increasing the competence of higher quality employees to produce better performance and quality.
\end{abstract}

Keywords - Intensification, Land and Building Tax (PBB) Collection

\section{INTRODUCTION}

One of the taxes that is a potential source of revenue for our country is PBB which is included in the State Tax category. Since 2011, the withdrawal of PBB has been delegated from the Central Government to City / Local Government in accordance with Regulation of Minister of Finance and Minister of Home Affairs number: 213 / pmk.07 / 2010, number: 58 year 2010 concerning Land and Building Tax Transfer Preparation Stages of Rural and Urban as Local Taxes. PBB is a fee that is imposed on a person or entity that actually has rights, owns, controls and benefits from the land and buildings.

Each year Local Government has a target in PBB revenue as a source of local income, but this target is not always fully realized [1]. Sometimes the realization of PBB revenue is far below the target set by Local Government. Based on Law Number 28 of 2009 about Land and Building Tax which becomes the object of land and building tax in rural and urban areas, are land and / or buildings that are owned, controlled, and / or utilized by private person or entities, except for areas used for plantation activities, forestry and mining businesses. What is meant by land is the surface and earth's body underneath. The surface of the earth includes land, water, interior and sea of Indonesian Territory while what is meant by building is a technical construction that is permanently planted or placed on the land and or water. Besides that, what is meant by subject of land and building tax is an entity that actually: (1) Has a right to the land and/or has benefits over the land; (2) Own, control and will benefit from the building [2] .

Related with PBB revenues, as happened in Barru District which is considered still have several deficiencies especially the low participation of the society in the payment of land and building taxes which is their obligation. Based on secondary data obtained by researchers related to arrears in PBB payments by each sub-District, where there are three sub-Districts in Barru District which are considered to be often in arrears, it can be seen in the figure below.

\section{DELINQUENT TAX DATA}
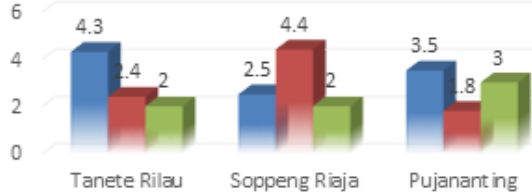

m $2017=2018=2019$

Source: District Revenue Office of Barru, 2019

Based on data above, there were three sub-Districts that arrears PBB in 2017, namely Taneter Rilau sub-District by 4.3 percent, Soppeng Riaja sub-District by 4.4 percent and Pujananting sub-District by 3.5 percent. In addition, in 2019 there was a decrease in tax arrears, with the majority of the three sub-Districts with an average of 2.5 percent of the society which were arrears to pay PBB. Seeing such conditions, the government needs to increase the intensification of tax collection in order to increase state or local revenues, in particular the intensification of the PBB sector.

Looking at the condition of tax revenue received by the local government of Barru District which has decreased from 2017 to 2019, then through Permendagri Number 86 year 2017 about the procedures for planning, controlling and evaluating District development, the procedures of evaluating draft District regulations regarding development plans Long-term District and District medium-term development plans, as well as the procedures for changes to 
long-term District development plans, District medium-term development plans, and local government work plans, as well as amendments to PP 02 year 2018 about Minimum Service Standards (SPM). Based on this, District Revenue Agency (BPD) of Barru needs to prepare and set the Revised Strategic Plan (Renstra) of BPD of Barru year 2016-2021.

Change Performance Plan in 2018 the Government of Barru District reconstructed program policies to direct more effective target achievement, so programs and activities were arranged whose implementation was regulated through policies set by the leader. In accordance with the purposes and objectives of BPD of Barru, the strategy that will be carried out in 2016-2021 period is intensification and extensification of local income from taxes and levies, particularly land and building taxes. By intensification, the focus is on whether or not the taxpayer has reported all existing tax objects with the actual amount. The emphasis is on the technical problem of tax collection. In general, it is done by counseling, in various ways and through various media.

\section{METHODOLOGY}

This study used qualitative method with a qualitative descriptive approach, where this method is an investigation that is carried out to provide a clear picture of the problems being studied, namely the Intensification of PBB collections in DISPENDA of Barru. Sources of data used in this study were primary data through interviews and secondary data through observation and documentation [3][4]. Technique of data collection was done by observation by making intensive direct observations. Moreover, this study also used interview technique as the main media. The data analysis used was interactive model by Miles, namely data condensation, data presentation and conclusion drawing / verification) [5].

\section{RESULT AND DISCUSSION}

The intensification of PBB collection at DISPENDA of Barru was found that the implementation of PBB collection at DISPENDA of Barru is not good enough. In the tax collection system, tax administration plays an active role in carrying out the tasks of guidance, service, supervision and application of penalty against delay of fulfilling tax obligations based on the existing provisions on the tax regulations. The supervisory function plays a very important role in tax collection because without supervision in a condition that the level of taxpayer compliance is still low, it results in the collection not going well, so that taxpayers will carry out their tax obligations incorrectly and in the end the revenue from the tax sector will not be achieved. Therefore, in measuring the intensification of PBB collection, it is not only seen from whether or not the taxpayer is obedient in carrying out its obligations, but also can be seen from the extent to which the tax apparatus provide counseling, services and audits [6].

The intensification of land and building tax collection at DISPENDA of Barru considered being inadequate implementation. This is viewed in terms of coverage, services, and audits which are indicators of intensification of PBB collection at DISPENDA of Barru.

\section{1) Counseling}

Before the transition of PBB from central to district government, extension was one of the duties of the tax apparatus according to the Taxation Law. The development of the taxpayer community can be done through various ways, such as providing information about taxation through mass media and direct information to the society. It can be seen before the transition, Directorate General of Taxes (DGT) in collaboration with District Government have made tax education efforts either through electronic media or printed media. In accordance with the results of interviews from several informants, both from the apparatus and from taxpayers stated the same thing that the DGT in collaboration with local governments (sub-Districts and Regional Technical Implementation Unit (UPTD) DISPENDA) had conducted counseling on taxes.

Counseling is carried out by DISPENDA of Barru District provides general explanation about the importance of carrying out obligations as taxpayers and also provides guidance or some kind of appeal to the taxpayers to be more obedient and on time in reporting their Annual Tax Return (SPT) as well as paying taxes. Usually, counseling is done by visiting agencies and each District and also through online media. The importance of counseling is done by DISPENDA so that all people realize the importance of paying land and building taxes because taxes are one of the biggest factors for the growth of a region. As stated by Mardiasmo that "counseling is a process of education or dissemination and the explanation of information which is an important in raising taxpayers awareness to pay taxes [7][8]."

Counseling that is always carried out by giving direct or indirect appeals to the entire societies to be more obedient in paying taxes, especially PBB. Counseling is an important factor in creating taxpayer awareness to carry out their tax obligations. By doing counseling, taxpayers can be reminded to pay taxes on time. Counseling can not only be done with direct information but also by utilizing mass media and electronic media [9].

\section{2) Service}

One of the efforts to improve taxpayer compliance is by providing good service to taxpayers. Improving service quality is expected to increase satisfaction to taxpayers as customers so as to increase compliance in the tax field. The new paradigm that places the government apparatus as regulating the state and society (taxpayers) must be prioritized in order to improve the performance of public services. The results are the services provided by DISPENDA employees of Barru District are not optimal, but DISPENDA of Barru District continues to improve the quality of services to increase taxpayer satisfaction and compliance.

To realize the income of Barru District to be more optimal through the income of $\mathrm{PBB}$, it is necessary to provide an excellent service system to the society as taxpayers. 
The motivation of taxpayers to pay $\mathrm{PBB}$ will decrease if the service is not good. It is explained by Ilyas and Pandu Wicaksono that "one of the efforts to improve taxpayer compliance is provide good service to the taxpayers [10].

Other efforts such as expanding Service Points, the use of information system and technology facilitate taxpayers in fulfilling their tax obligations. The services provided by DISPENDA of Barru District have gone well and according to procedures. Good service is one of the main factors in achieving the increase of taxpayer compliance. As previously explained, the role of tax apparatus in the tax collection system is to provide services to taxpayers. It can be seen from the fact in Barru District that the collection is carried out intensively because the services provided by the apparatus have a positive impact on taxpayers to fulfill their obligations.

\section{3) Audit}

Tax collection begins with an audit. If the inspection has been carried out, then a Notice of Tax Assessment (SKP) is issued. The level of taxpayer compliance in fulfilling tax obligations is the main objective of tax audits, so for taxpayers whose compliance level is still low, it is hoped that the inspection can provide positive motivation so that in the future the level of compliance will be better. From the information that the author got at the UPTD PBB, if the taxpayer still does not want to fulfill his obligations in paying taxes, then a sanction will be given which will involve the Satpol PP officers to inspect the place of the Taxpayer concerned. However, before that was done, there will be a tax audit and investigation first of the taxpayer.

According to Lubis (2011: 93), one of the ways that can be taken in an intensification effort is supervision because without any supervision for taxpayer compliance in paying land and building taxes [11][12]. It is hoped taxpayers do not break the taxpayers' fulfillment of their tax obligations. Therefore, a Tax Audit is held based on the Decree of the Minister of Finance Number 545 / KMK.04 / 2000 article 1 number 1 about Tax Audit Procedures, an audit is defined as "a series of activities to seek, collect, manage data and / or other information to test compliance with the fulfillment of tax obligations and for other purposes in order to implement the provisions of tax laws and legislation."

The supervision which is conducted by DISPENDA of Barru through the file inspection system done by DISPENDA Barru employees has not been able to run properly. This is due to the lack of employee resources assigned to check files and employees who will review a location proposed by the applicant. In addition, the process of checking files done by employees sometimes does not follow the procedures set out by DISPENDA of Barru. For Instance, the employee who checks the applicant's file which is clear that the file still needs to be repaired because there are still deficiencies in the file, but the employee still allows the file to pass.

The intensification of PBB collection in DISPENDA of Barru is also influenced by the quality of an employee resource which is known that human resources is needed in every agency, especially in DISPENDA of Barru where the duties of employees in this office are not only in serving the people who take care of the PBB but also these employees have another task that is to examine every file proposed by the society in the making of PBB, or PBB submissions that are problematic from the community itself. In doing each task, it requires a lot of expertise and knowledge from employees in carrying out each job.

Based on the results of the research, it is found that currently existing employees in DISPENDA of Barru especially those who handle $\mathrm{PBB}$ management still need to improve the quality of their performance starting from competency knowledge and expertise. With this problem, it can be concluded that currently the quality of employees in DISPENDA has so far been considered quite competent in their duties, but the Government of Barru still needs to improve the quality of employee resources in DISPENDA of Barru to be able to create more reliable employee resources, professional, honest in carrying out every task that is their responsibility.

The good performance of DISPENDA employees is determined by their ability to carry out any existing work, therefore DISPENDA needs to equip employees by providing training and improving their education. In addition, the leader also needs to pay attention to every employee who has achievement to be given an award because it motivated the employees to work better than before [13].

Efforts to optimize the intensification of PBB collection at DISPENDA of Barru can also be done several activities. Firstly, maintenance and repair of $\mathrm{PBB}$ database per sub-District by updating data at any time when there is a process for correcting $\mathrm{PBB}$ tax object data, processing objections to Notification of Tax Due (SPPT), and all related concerning PBB tax object. Secondly, strengthening the collection process is carried out by stipulating Perda No. 10/2010 concerning Village / Urban Land and Building Taxes and increasing the capacity of human resources by holding several training activities that are attended by all employees involved in PBB activities [14][15].

Thirdly, increase supervision of tax objects through several activities, such as examining tax object data, examining the condition of tax objects, and problems. Fourthly, increase administrative efficiency by optimizing current technological developments so it is able to facilitate all activities related to administrative activities and to minimize administrative costs. Fifthly, the Government of Barru District in collaboration with DISPENDA of Barru is coordinating with several related agencies such as subdistricts, urban villages, villages, and all parties involved in PBB collection activities. Sixthly, the socialization is carried out by some methods such as banners, mass media, and others.

\section{CONCLUSION}

To sum up, the intensification of land and building tax collection at DISPENDA of Barru has not been going well. In addition, improving the quality of tax collector employees at DISPENDA of Barru can be categorized as quite good. Several suggestions are put forward that can be 
used as recommendations for DISPENDA of Barru in making a decision or policy in handling the problem of collecting land and building taxes as follows: 1) It is hoped that the Head of DISPENDA will always conduct counseling related to $\mathrm{PBB}$ and improve quality of DISPENDA employees through training activities and providing opportunities to continue the education level; 2) it is hoped that DISPENDA of Barru employees to do counseling to the society; 3 ) it is expected that DISPENDA can be more innovative in creating $\mathrm{PBB}$ payment service system that ease the people to pay PBB; 4) it is expected that the Government of Barru District will always monitor the performance of DISPENDA of Barru, especially in the issue of tax collection.

\section{ACKNOWLEDGMENT}

Thanks to the Dean of the Faculty of Social Sciences who have provided financial support for this research. Furthermore, I thank DiSPENDA Barru who have helped in providing data in the form of primary data and secondary data in the success of the research conducted.

\section{REFERENCES}

[1] M. Rum, "Conversion of Federal Tax Collection to Local Government," Int. Res. J. Financ. Econ., no. 165, 2018.

[2] R. K. Kasanga and N. A. Kotey, "Land management in Ghana: Building on tradition and modernity." International Institute for Environment and Development London, 2001.

[3] A. Anggito and J. Setiawan, Metodologi penelitian kualitatif. CV Jejak (Jejak Publisher), 2018.

[4] I. Gunawan, "Metode penelitian kualitatif," Jakarta Bumi Aksara, vol. 143, 2013.

[5] M. Huberman and M. B. Miles, The qualitative researcher's companion. Sage, 2002.

[6] D. Nur Pertiwi, "The Influence of Tax Consciousness, Service Tax Authorities and Tax Sanctions on Tax Compliance (Survey On Individual Taxpayer Conducting Business Operations and Professional Service in Jakarta)." 2013.

[7] M. R. Palil, "Tax knowledge and tax compliance determinants in self assessment system in Malaysia." University of Birmingham, 2010.

[8] I. Mukhlis, S. H. Utomo, and Y. Soesetyo, "Increasing tax compliance through strengthening capacity of education sector for export oriented SMEs handicraft field in East Java Indonesia," Eur. Sci. J., vol. 10, no. 7, 2014.

[9] B. Marcus, N. Owen, L. Forsyth, N. Cavill, and F. Fridinger, "Physical activity interventions using mass media, print media, and information technology," Am. J. Prev. Med., vol. 15, no. 4, pp. 362-378, 1998.

[10] E. Savitri, "The effect of tax socialization, tax knowledge, expediency of tax ID number and service quality on taxpayers compliance with taxpayers awareness as mediating variables," Procedia-social Behav. Sci., vol. 211, pp. 163-169,
2015.

[11] M. Suryanto, B. Hermanto, P. S. Kurniati, and M. Rasmini, "Strategy of Increasing of Local Tax Revenues in Bandung City," in International Conference on Public Policy, Social Computing and Development 2017 (ICOPOSDev 2017), 2017.

[12] I. Awaluddin and S. Tamburaka, "The Effect of Service Quality and Taxpayer Satisfaction on Compliance Payment Tax Motor Vehicles at Office One Roof System in Kendari," Int. J. Eng. Sci., vol. 6, no. 11, pp. 25-34, 2017.

[13] K. Breevaart, A. Bakker, J. Hetland, E. Demerouti, O. K. Olsen, and R. Espevik, "Daily transactional and transformational leadership and daily employee engagement," J. Occup. Organ. Psychol., vol. 87, no. 1 , pp. 138-157, 2014.

[14] T. Lievens et al., "Creating incentives to work in Ghana: Results from a qualitative health worker study," 2011.

[15] N. R. C. (US). C. on a S. of N. N. for Biomedical and B. R. Personnel, Personnel Needs and Training for Biomedical and Behavioral Research: The 1978 Report of the Committee on a Study of National Needs for Biomedical and Behavioral Research Personnel, Commission on Human Resources, National Research Council, vol. 1. National Academies, 1978. 